\title{
NEIŠNEŠIOTŲ NAUJAGIMIŲ, GIMUSIŲ VILNIAUS MIESTO KLINIKINĖJE LIGONINĖJE, MAITINIMAS. ŽINDYMO SĖKMĘ NULE்ME VEIKSNIAI
}

\author{
Vita Langiené, Violeta Drejerienè \\ Vilniaus miesto klinikine ligonine, Naujagimiu skyrius
}

Raktažodžiai: vèlyvi neišnešioti naujagimiai, žindymo trukmè, naujagimiui palanki ligoninè.

\begin{abstract}
Santrauka
Tyrimo tikslas. Išanalizuoti 1 metų duomenis apie Vilniaus miesto klinikinejje ligonineje (VMKL) gimusių vẻlyvų neišnešiotų naujagimių maitinimą, îvertinti gestacinio amžiaus įtaka natūralaus maitinimo dažniui.

Metodika. Atlikta retrospektyvinè 2015 m. - $2016 \mathrm{~m}$. VMKL gimusių neišnešiotų naujagimių raidos istorijų analizè. Šių gimusių kūdikių tolesnio maitinimo analizei atlikti ir įvertinti buvo sudaryta ir naudota retrospektyvi motinų apklausos anketa.

Rezultatai. Iš 100 tyrime dalyvavusių vẻlyvų neišnešiotų naujagimių iš stacionaro išimtinai žindomi išvyko 78 (78 proc.). Vèlyvi neišnešioti naujagimiai statistiškai rečiau išvyko natūraliai maitinami neišnešioti naujagimiai $(p<0,05)$. Didžioji dalis vèlyvų neišnešiotų naujagimių ( $\mathrm{n}=92,92$ proc.) toliau sẻkmingai žindyti iki 3 mèn., 88 ( 88 proc.) iki 6 mèn., 51 (51 proc.) iki 12 mèn., 24 (24 proc.) iki $\geq 18$ mèn. Išnešiotų ir vẻlyvų neišnešiotų kūdikių iki $6-18$ mènesių amžiaus natūralaus maitinimo ir sėkmingo žindymo rezultatai praktiškai vienodi.

Išvados. Vèlyvi neišnešioti naujagimiai po gimimo rečiau natūraliai maitinami nei išnešioti naujagimiai $(p<0,05)$. Tačiau ženklaus skirtumo tarp tolimesnio šių naujagimių sèkmingo žindymo dažnio nenustatème.
\end{abstract}

\section{Ivadas}

VMKL Akušerijos ir ginekologijos klinika yra įsipareigojusi tapti naujagimiams palankia ligonine (NPL), personalas kasdieniame darbe diegia ir vykdo žindymo programos nuostatas. VMKL yra antrinio B lygio paslaugas gimdyvėms ir naujagimiams teikianti įstaiga, tad ligonineje gimsta ne tik išnešioti naujagimiai, bet ir vèlyvi neišnešioti naujagimiai, kurie ankstyvuoju naujagimystès laikotarpiu neretai susiduria su jiems būdingomis sveikatos problemomis. 2016-2017 metais vykdėme analizę apie VMKL gimusių išnešiotų naujagimių maitinimą išvykstant iš gimdymo stacionaro: kiek buvo natūraliai maitinamų (išimtinai žindomų) naujagimių, kokią įtaką žindymo sèkmei turejjo gimimas po cezario pjūvio, iš daugiavaisio néštumo, naujagimių sergamumas ir kitos būklès. Ankstesnèse publikacijose pateikème VMKL gimusių išnešiotų naujagimių maitinimą, siekème mūsų duomenis palyginti su kitų Lietuvos ir užsienio šalių gimdymo stacionarų žindymo praktikos duomenimis, ịvertinti, kaip sėkmingas žindymas naujagimystejje nulemia tolesnị kūdikių, sulaukusių $18-24$ mėnesių amžiaus, maitinimą [1-3]. Atlikdami savianalizę siekème nustatyti, kaip toliau galètume pagerinti darbą vykdant naujagimiams palankios ir šeimai draugiškos ligoninès nuostatas. Tęsiant ankstesnius tyrimus, atlikome analizę apie vèlyvų neišnešiotų naujagimių, gimusių VMKL per tą patị 2016-2017 metų laikotarpi, maitinimą gimdymo stacionare, palyginome jų žindymo trukmę su išnešiotais naujagimiais.

Tyrimo tikslas: išanalizuoti 1 metų duomenis apie VMKL gimusių vẻlyvų neišnešiotų naujagimių maitinimą išvykstant į namus, bendrai apibūdinti jų sergamumą ir sergamumo struktūrą; ịvertinti gestacinio amžiaus įtaką natūralaus maitinimo dažniui gimdymo stacionare. Kokia vẻlyvų neišnešiotų naujagimių žindymo trukmė pirmaisiais gyvenimo metais motinų apklausos duomenimis; kokios dažniausios priežastys lèmè ankstyvą natūralaus maitinimo nutraukimą; palyginti vèlyvų neišnešiotų ir išnešiotų naujagimių ir kūdikių maitinimo duomenis.

\section{Tyrimo objektas ir metodika}

Naujagimis, kurio intrauterininis gestacijos amžius yra nuo 37 iki 41(+6 d.) savaitès, yra išnešiotas, laiku gimęs. Neišnešiotais naujagimiais laikomi prieš laiką gimę: nuo 22 iki 36 (+6 d.) gestacijos savaičių [4]. Pasaulio sveikatos 
organizacijos (PSO) duomenimis, neišnešioti naujagimiai yra skirstomi pagal jų gestacijos laiką: ypač neišnešioti, ypač mažo gestacijos amžiaus (YMGA) ( $<28$ savaičių), labai neišnešioti (nuo 28 iki 32 savaičių) ir vèlyvi neišnešioti naujagimiai, kurie gimę nuo 32 iki 36 (+6 d.) savaičių [5]. Vèlyvi neišnešioti naujagimiai sudaro apie 75 proc. visu gimusių neišnešiotų naujagimių [6].

Medicinos mokslo pažanga naujagimių intensyviojoje priežiūroje labai padidino neišnešiotų naujagimių išgyvenamumą. Ivairiose pasaulio šalyse priešlaikinių gimdymų dažnis svyruoja nuo 5 iki 18 procentų [7].

Lietuvoje kiekvienais metais gimsta apie 30000 naujagimių, iš kurių apie 5-6 proc. - neišnešioti [8]. 2016 metais mūsų šalyje gimė 1622 neišnešioti naujagimiai (5,6 proc.), iš jų 1382 buvo gimę 32-36 gestacijos savaičių [9].

Neišnešiotų naujagimių maitinimą nulemia ịvairūs veiksniai. Išskiriamos trys naujagimių maitinimo rūšys.

Natūralus maitinimas (žindymas) - naujagimio maitinimas iš krūties arba nutrauktu motinos pienu. Tai procesas, kuriam būtinas sąmoningas motinos apsisprendimas ir noras žindyti. Pagrindinis sẻkmingai žindomo naujagimio požymis yra gera bendroji naujagimio būklè, jis aktyviai žinda, svoris kinta pagal amžiaus normas, kūdikis normaliai tuštinasi ir šlapinasi. Mišrus maitinimas - kai naujagimis maitinimas ne tik motinos pienu, bet papildomai maitinamas motinos pieno pakaitalais. Neišnešiotus, sergančius ar sergančios gimdyvės naujagimius, kai yra nepakankama laktacija, pirmomis paromis po gimimo neretai tenka papildomai primaitinti pieno mišiniais. Dirbtinis maitinamas - kai naujagimiai visiškai negauna motinos pieno ir yra maitinami tik motinos pieno pakaitalais, adaptuotais pieno mišiniais [10].

Neišnešioto naujagimio maitinimo būdas priklauso nuo intrauterinio amžiaus, kūno svorio, naujagimio ir motinos sveikatos būklès ir kt. Čiulpimo refleksas atsiranda 24-ą gestacinio amžiaus savaitę, nuo 32 gestacijos savaičių čiulpimo refleksas sustiprèja, nuo 32-34 savaičių jis jau suderintas su rijimo refleksu. Nuo 34 gestacijos savaičiu jau suderinamos visos funkcijos: čiulpimas, rijimas ir kvèpavimas, taigi, daugelis 34-35 gestacijos savaičiu naujagimiu sėkmingai žinda po gimimo. 35-36 gestacijos savaičių naujagimiai, jeigu jų būklè gera, prižiūrint medikams, pirmajam žindymui gali būti pridèti prie krūties jau per pirmąsias 2 valandas po gimimo [4].

Nustatyta, kad 34 gestacijos savaičių naujagimio smegenys sveria 35 proc. mažiau nei išnešioto naujagimio smegenys, vèliau, per sekančias 6-8 savaites, naujagimio galvos smegenys paauga ir būtent per ši laikotarpi baltosios smegenų substancijos padaugeja 5 kartus, pilkosios smegenų masès padaugèja 10 kartų. Ištirta, kad per ši laikotarpi motoriniai naujagimio ịgūdžiai labiau subręsta ir tampa labiau koordinuoti. Todèl labai svarbu, kad esant priešlaikiniam gimdymui tèvai būtų informuoti, žinotų, kad neišnešiotas naujagimis ne tik dèl didesnio sergamumo, bet ir dèl galvos smegenų nebrandumo gali neturèti pakankamų gebejjimų žịsti. Pasiekus tam tikrą koreguotą naujagimio amžių, žindymo sunkumų ženkliai sumažeja [10].

Nustatyta, kad vèlyvi neišnešioti naujagimiai rečiau išimtinai žindomi nei išnešioti . Jiems dèl ženkliai didesnio sergamumo, sumažinto bendro aktyvumo, nebrandumo gali būti sunkiau taisyklingai apžioti krūtí, jie greičiau pavargsta, dažniau būna nepakankamas gebėjimas vienu metu žįsti ir suderintai kvėpuoti [11]. Tokiems naujagimiams tenka ilgiau gulèti ligoninèje, neretai, kol stabilizuojama būklè, jie slaugomi, gydomi intensyviosios terapijos palatoje. Motinos mokomos, kaip nutraukti pieną rankomis, kol jų naujagimiai yra atskirti, tévai palaipsniui mokomi kaip prižiūreti ir maitinti naujagimį. Tik įsitikinus, kad naujagimis yra geros būklès (pakankamai aktyvus, gerai žinda ir gerai įsisavina reikiamą pieno kiekį, stabilios būklès, užtikrinamas normalus svorio augimas, normaliai šlapinasi, tuštinasi ir kt.) gali būti išrašomas į namus. Naujagimių, ypač vẻlyvų neišnešiotų naujagimių, natūralus maitinimas išvykstant iš ligoninès yra medicinos personalo rūpestingo ir profesionalaus kasdienio darbo rezultatas, parodantis, kaip vykdomos naujagimiams palankios ir šeimai draugiškos ligoninès nuostatos. Be šiandienos darbo analizès negalètume teigti, kokia mūsų patirtis yra šiandien, palyginti su kitų Lietuvos ir užsienio šalių gimdymo stacionarų darbo rezultatais, negalètume ateityje palyginti savo pačių darbo rezultatų pokyčių.

Atlikta retrospektyviné 2015-2016 m. VMKL gimusių neišnešiotų naujagimių raidos istorijų analizè. Šių gimusių kūdikių tolesnio maitinimo analizei atlikti ir ịvertinti buvo sudaryta ir naudota retrospektyvi motinų apklausos anketa.

Tyrimo objektas - VšI Vilniaus miesto klinikinèje ligoninèje nuo 2015 m. rugsèjo iki $2016 \mathrm{~m}$. rugpjūčio mènesio įskaitytinai gimę ir iš gimdymo stacionaro išrašyti, išvykę i namus, vẻlyvi neišnešioti naujagimiai nuo 34 iki 36 savaičių gestacinio amžiaus. Šių naujagimių grupès apibūdinimui pasirinkome jų sergamumo ir sergamumo struktūros rodiklius.

Tiriamujų naujagimių atranka ir tyrimo metodas. VMKL $2015 \mathrm{~m}$. rugsejjo - $2016 \mathrm{~m}$. rugpjūčio mẻnesiais iš viso gimé 2892 naujagimiai, iš jų 126 (4,4 proc.) neišnešioti, iš kurių 14 neišnešiotų naujagimių (11 proc.) gimè labai neišnešioti, mažiau 32-33 gestacijos savaičių amžiaus, - toliau ị mūsų tyrimus jų neįtraukème, jie buvo perkelti ị neonatologijos centrą. Išskirtos 2 tiriamujų naujagimių grupès: 1 gr. - vèlyvi neišnešioti naujagimiai 34-36 gestacijos savaičių, 2 gr. (kontrolinė grupè) - išnešioti naujagimiai. Vèlyvų neišnešiotų naujagimių grupè (1 gr.), vertinant jų maitinimo pobūdį, buvo išskirta ị 3 pogrupius pagal gestacinį amžių: $34-35-36$ 
gestacijos savaičių. Apklausème 112 moterų, pagimdžiusių vèlyvus neišnešiotus naujagimius per nurodytą laikotarpį. I iš anksto sudarytos apklausos anketos klausimus sutiko atsakyti 100 moterų. Kontrolinę, 2 grupę, sudare 2766 išnešioti naujagimiai, gimę tuo pačiu laikotarpiu, nuo $2015 \mathrm{~m}$. rugsėjo iki 2016 m. rugpjūčio mènesio įskaitytinai.

Statistinès duomenų analizès metodai. Duomenų kaupimui ir statistinei analizei panaudotos „Excel 97-2003“ ir „Statistical Packages for Social Sciences“ (SPSS 17) programos.

Duomenų analizės kokybinių požymių statistinis ryšys vertintas taikant Pirsono (Pearsono) chi kvadrato $\left(\chi^{2}\right)$ kriterijų. Reikšmingumo lygmuo pasirinktas 0,05 . Statistiškai patikimu kokybinių požymių skirtumų rezultatas buvo laikomas, jei $\mathrm{p}<0,05$.

\section{Rezultatai}

Tirtų vẻlyvų neišnešiotų naujagimių sergamumas ir sergamumo struktūra. Iš 100 tyrime dalyvavusių vẻlyvų neišnešiotų naujagimių 55 buvo gimę 36 gestacijos savaičių (55 proc.), 30 - 35 savaičiu ( 30 proc.), 15 - 34 sav. (15 proc.). 20 naujagimių ( 20 proc.) gimè iš daugiavaisio něštumo (tyrime dalyvavo dešimt dvynukų porų).

15 neišnešiotų naujagimių ( 15 proc.) po gimimo nesirgo. Nustatėme, kad vẻlyvų neišnešiotų naujagimių sergamumas buvo 850/1000 gyvų gimusių naujagimių. Vyraujanti patologija buvo: igimta infekcija ( $\mathrm{n}=33,33$ proc.), kvėpavimo sutrikimo sindromas $(\mathrm{n}=21,21$ proc.), hiperbilirubinemija $(\mathrm{n}=19,19$ proc.) (1 paveikslas). Daugumai vèlyvų neišnešiotų naujagimių buvo nustatyta dauginè patologija.

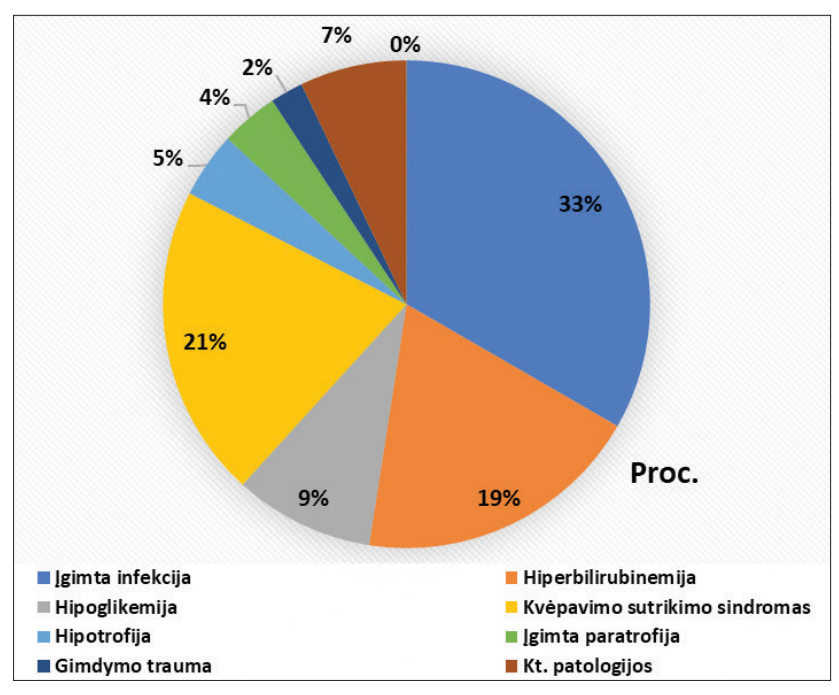

1 paveikslas. Tirtų vẻlyvų neišnešiotų naujagimių sergamumo struktūra.
Mūsų duomenimis, iš 100 tirtų 1 grupès naujagimių 78 vèlyvi neišnešioti naujagimiai išvykstant iš gimdymo stacionaro buvo maitinti tik natūraliai (1 lentelè). Vertinant naujagimių natūralaus maitinimo dažnị skirtingo gestacinio amžiaus pogrupiuose, rezultatų skirtumo statistinio patikimumo nenustateme $(p>0,05)$.

Mūsų duomenimis, kontrolinès, 2 grupès, išnešiotų naujagimių natūraliai maitinamų išvyko iš stacionaro 2438 iš 2766 gimusių ( 88.2 proc.). Išnešioti naujagimiai statistiškai dažniau buvo natūraliai maitinami negu neišnešioti 1 grupès naujagimiai $(\mathrm{p}<0.05)(2$ lentelè).

Naujagimių ir kūdikių tolesnè žindymo trukmė motinų apklausos duomenimis. 62 motinos (62 proc.) teigè, kad išvykdamos iš gimdymo stacionaro vèlyvus neišnešiotus (1 gr.) naujagimius tik žindė; 34 (34 proc.) - maitino mišriai ir 4 (4 proc.) - maitino dirbtinai. Daugelis šios grupès mamų ( $\mathrm{n}=92,92$ proc.) toliau sèkmingai žinde kūdikius iki 3 mèn., 88 (88 proc.) iki 6 mèn.; 51 (51 proc.) žindè iki 12 mèn.; 24 ( 24 proc.) - iki $\geq 18$ mèn. Šie duomenys beveik nesiskyrè nuo išnešiotų 2 gr. kūdikių žindymo trukmès (2 pav.).

Dažniausios priežastys, nulẻmusios ankstyvą žindymo nutraukimą. Motinų apklausos duomenimis, dažniausios ankstyvo maitinimo nutraukimo priežastys (iki 6 mėnesių) buvo nepakankamas pieno kiekis, kūdikio atsisakymas žįsti, staigus pieno „dingimas“. Vèlyvų neišnešiotų ir išnešiotų naujagimių žindymo ankstyvo nutraukimo priežastys buvo panašios ( 3 pav.).

\section{Rezultatų aptarimas}

Tyrimo metu nustateme, kad didžioji dalis (78 proc.) vẻlyvų neišnešiotų naujagimių iš VMKL išvyksta išimtinai žindomi. Anketinès apklausos duomenimis, 62 (62 proc.) motinos teige, kad neišnešiotus naujagimius išvykstant iš ligoninès natūraliai maitino - žindè. Manome, kad šių duo-

1 lentelė. Vèlyvų neišnešiotų naujagimių maitinimas.

\begin{tabular}{|c|c|c|c|c|c|c|}
\hline \multirow{2}{*}{$\begin{array}{l}\text { Gestaci- } \\
\text { nis am- } \\
\text { žius } \\
\text { (sav.) }\end{array}$} & \multirow{2}{*}{$\begin{array}{l}\text { Nauja- } \\
\text { gimių } \\
\text { skai- } \\
\text { čius n }\end{array}$} & \multicolumn{2}{|c|}{$\begin{array}{c}\text { Natūraliai } \\
\text { maitinti }\end{array}$} & \multicolumn{2}{|c|}{$\begin{array}{l}\text { Mišriai } \\
\text { maitinti }\end{array}$} & \multirow{2}{*}{$\begin{array}{c}\begin{array}{c}\text { Dirbti- } \\
\text { nai } \\
\text { maitint }\end{array} \\
0 \\
\end{array}$} \\
\hline & & $\mathrm{n}$ & Proc. & $\mathrm{n}$ & Proc. & \\
\hline 34 & 15 & 14 & 93 & 1 & 67 & 0 \\
\hline 35 & 30 & 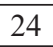 & 80,0 & 6 & 20,0 & 0 \\
\hline 36 & 55 & 40 & 72,7 & 15 & 27,3 & 0 \\
\hline Iš viso & 100 & 78 & 78 & 22 & 22 & 0 \\
\hline
\end{tabular}

2 lentelè. Išnešiotų naujagimių maitinimas.

\begin{tabular}{|l|c|c|c|c|c|c|}
\hline $\begin{array}{l}\text { Naujagi- } \\
\text { mių skai- }\end{array}$ & \multicolumn{2}{|c|}{$\begin{array}{c}\text { Natūraliai } \\
\text { maitinti }\end{array}$} & \multicolumn{2}{|c|}{$\begin{array}{c}\text { Mišriai } \\
\text { maitinti }\end{array}$} & \multicolumn{2}{|c|}{$\begin{array}{c}\text { Dirbtinai } \\
\text { maitinti }\end{array}$} \\
\cline { 2 - 7 } & $\mathrm{n}$ & Proc. & $\mathrm{n}$ & Proc. & $\mathrm{n}$ & Proc. \\
\hline 2766 & 2438 & 88,2 & 316 & 11,4 & 12 & 0,4 \\
\hline
\end{tabular}


menų neatitikimo priežastis galèjo būti skirtingas natūralaus maitinimo interpretavimas, - motinų supratimu natūraliu maitinimu įvardijamas tik žindymas, jų nuomone, maitinimas nutrauktu motinos pienu nepriskiriamas natūraliam maitinimui.

Mūsų tirtų neišnešiotų naujagimių didelis sergamumas, neretai dauginè ankstyvojo naujagimystès laikotarpio patologija, gimimas iš daugiavaisio néštumo galèjo nulemti jų maitinimo ypatumus. Ateityje turètume išsamiau ištirti ir ịvertinti ne tik vėlyvų neišnešiotų naujagimių sveikatos būklę, bet ir kitus perinatologinius veiksnius, gimdyvès sveikatą, laktacijos ypatumus, gimimą po cezario pjūvio ir kitus veiksnius, įtakojusius neišnešiotų naujagimių maitinimą.

Mūsų tyrimo rezultatai statistiškai patikimai patvirtino, kad vèlyvi neišnešioti naujagimiai rečiau maitinami natūraliai negu išnešioti, tačiau vèliau, abiejų grupių kūdikiai iki 6- 18 ir daugiau mėnesių amžiaus, praktiškai vienodai sékmingai yra žindomi.

Palyginti mūsų tyrimo duomenis su kitų ligoninių ar šalių duomenimis labai sunku, kadangi literatūros šaltiniuose

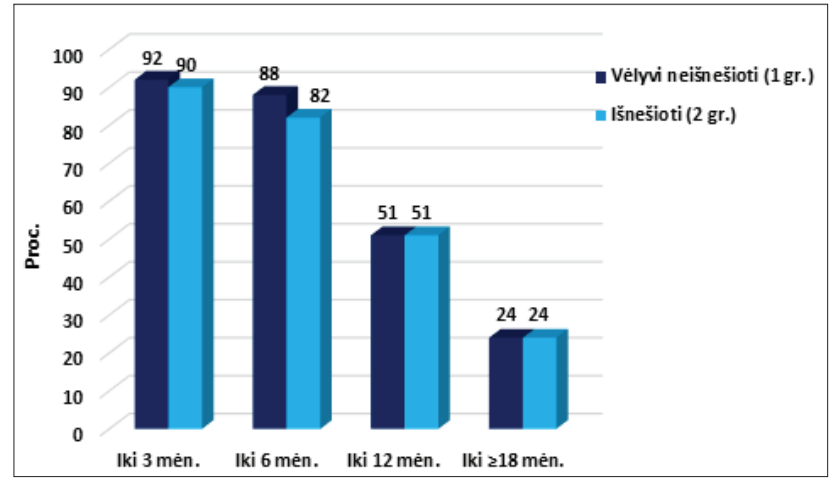

2 paveikslas. Vèlyvų neišnešiotų ir išnešiotų gimusių kūdikių žindymo trukmè.

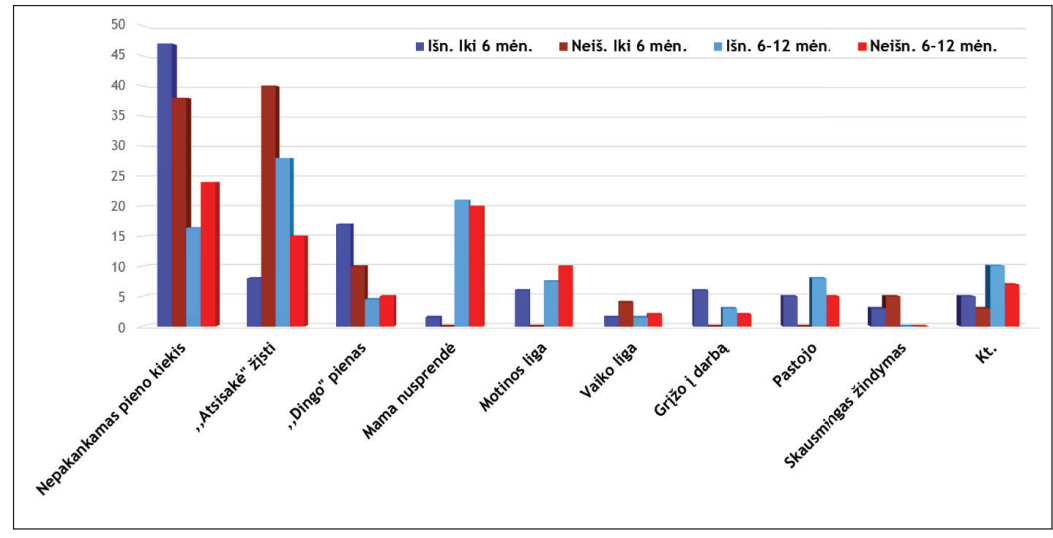

3 paveikslas. Dažniausios kūdikių žindymo ankstyvo nutraukimo priežastys. pavyko rasti tik vieną panašaus pobūdžio tyrimą. Panašus vẻlyvų neišnešiotų naujagimių žindymo vertinimas buvo atliktas Vakarų Kanadoje Kalgari mieste. Buvo apklaustos 74 moterys, susilaukusios vėlyvo neišnešioto naujagimio 2013-2014 m. Apklausos metu jų naujagimiams buvo 6-8 gyvenimo savaitès. Iš 74 kūdikių, 51 (68,9 proc.) buvo maitinamas mišriai ir tik 10 (13,5 proc.) buvo išimtinai žindomi.

Šio mūsų tyrimo rezultatai, manytume, yra išties džiuginantys, kadangi didžioji dalis naujagimių buvo ne tik sèkmingai pradèti žindyti stacionare, bet ir toliau žindomi išvykę i namus -88 proc. vèlyvų neišnešiotų naujagimių pirmus 6 gyvenimo mėnesius buvo sèkmingai žindomi. Tolimesnè vẻlyvų neišnešiotų naujagimių žindymo trukmè iki 12-18 mẻnesių ir ilgiau taip pat ženkliai nesiskyrè lyginant su išnešiotų kūdikių. Tai rodo didelį neišnešiotų naujagimių mamų norą ir pastangas žindyti bei mūsų ligoninès akušerių ir naujagimių skyriaus medicinos personalo žinias ir praktinius gebejjimus užtikrinti, kad ir neišnešioti naujagimiai būtų pagal galimybes kuo anksčiau priglaudžiami prie krūties po gimimo, o su naujagimio nebrandumu susijusios žindymo problemos būtų sẻkmingai išsprendžiamos.

\section{Išvados}

1. Natūraliai maitinami iš VMKL gimdymo stacionaro išvyksta 78 procentai gimusių vẻlyvų neišnešiotų naujagimių.

2. VMKL gimdymo stacionare išnešioti naujagimiai statistiškai dažniau maitinami natūraliai negu gimę vèlyvi neišnešioti naujagimiai.

3. Gimusių išnešiotų ir vẻlyvų neišnešiotų kūdikių iki 6-18 ir daugiau mėnesių amžiaus natūralaus maitinimo ir sékmingo žindymo rezultatai yra praktiškai vienodi.

4. Iki 3 mènesių amžiaus išnešiotus kūdikius žindė 90 proc., vẻlyvus neišnešiotus 92 procentai motinų, iki 6 mènesių 82-88 proc., iki 12 mėnesių 54-51 proc., iki 18 mèn.

\section{4-24 proc.}

\section{Literatūra}

1. Drejerienė V, Langienė V, Strucienė J. Naujagimių maitinimas Vilniaus miesto klinikinèje ligonineje: kelias palankios naujagimiui ligoninès link. Medicinos teorija ir praktika, 2016; 22(4): 316-321. https://doi.org/10.15591/mtp.2016.051

2. Drejerienè V, Langienė V. Kūdikių žindymo sèkmę prasideda naujagimystejje. Preliminarūs duomenys apie naujagimius, gimusius Vilniaus miesto klinikinèje ligoninèje. Internistas, 2017; 9:11-13.

3. Drejerienè V, Langienė V, Kinčinienė $O$. Žindymo reikšmè naujagimiui ir motinai, 
veiksniai, turintys įtakos žindymui. Literatūros apžvalga, 2016; 22(4): 281-286.

4. Išnešioto ir neišnešioto naujagimio maitinimo rekomendacijos. Metodika, 2014; https://sam.lrv.lt/uploads/sam/documents/ files/Veiklos_sritys/Programos_ir_projektai/Sveicarijos_parama/Neonatologines_metodikos/Isnesioto $\% 20 \mathrm{ir} \% 20$ neisnesioto $\% 20$ naujagimio $\% 20$ maitinimo $\% 20$ rekomendacijos.pdf.

5. World Health Organization. Preterm birth, 2018 ; http://www. who.int/news-room/fact-sheets/detail/preterm-birth.

6. Kugelman A, Colin AA Late preterm infants: near term but still in a critical developmental time period. Pediatrics, 2013; Oct; 132(4):741-51. https://doi.org/10.1542/peds.2013-1131

7. Blencowe H, Cousens S, Oestergaard M, Chou D, Moller AB, Narwal R, Adler A, Garcia CV, Rohde S, Say L, Lawn JE. National, regional and worldwide estimates of preterm birth. The Lancet 2012;9;379(9832):2162-72.

8. Gimimų medicininiai duomenys. Vilnius, 2005-2015; http://sic.hi.lt/html/nrd.htm.

9. Gimimų medicininiai duomenys. Vilnius, 2016; http://www. hi.lt/uploads/pdf/leidiniai/Statistikos/Gimimu/116_gim.pdf.

10. Išnešioto ir neišnešioto naujagimio maitinimo rekomendacijos. Metodika, 2014; https://sam.lrv.lt/uploads/sam/documents/ files/Veiklos_sritys/Programos_ir_projektai/Sveicarijos_parama/Neonatologines_metodikos/Isnesioto $\% 20 \mathrm{ir} \% 20$ neisnesioto $\% 20$ naujagimio $\% 20$ maitinimo $\% 20$ rekomendacijos.pdf.

11. Hallowell SG, Spatz DL. The relationship of brain development and breastfeeding in the late-preterm infant. J Pediatr Nurs 2012;27:154-162.

https://doi.org/10.1016/j.pedn.2010.12.018
12. Abrams AS, Nancy MH. Breastfeeding the preterm infant, 2018; https:/www.uptodate.com/contents/breastfeeding-the-preterm-infant? search=preterm $\% 20$ baby $\% 20$ breastfeeding\&source $=$ search_result\&selectedTitle $=1 \sim 150 \&$ usage_type $=$ default\&display_rank $=1$.

\section{FACTORS LEAD TO SUCCESSFUL BREASTFEEDING} V.Langienè, V.Drejerienè

Key words: late preterm infants, breastfeenig duration, neobaby friendly hospital.

Summary

Objectives. Evaluate the influence of gestation age on the breastfeening duration.

Methods. Retrospective study. Data were collected in Vilnius city clinical hospital from September 2015 to August 2016. We analyzed the hystories of neonatals development and interviewed their mothers according to a prie-made questionnaire.

Results. In our study we included 100 late preterm infants neonates, $78 \%$ infants were breastfeeding at discharge moment. It was statistically significant, that term infants were more often breastfed than late preterm $(\mathrm{p}<0,05)$. Most of the late preterm neonates ( $\mathrm{n}=92,92 \%)$ continued breastfeeding for up to 3 months, 88 (88\%) to 6 months, 51 (51\%) to 12 months, 24 (24\%) to $\geq 18$ months.

Conclusions. It was statistically significant, that term infants were more often breastfed than late preterm infants $(p<0,05)$. However, we did not find significant difference between later breastfeeding duration of late preterm and term infants.

Correspondence to: vitai.gapsytei@gmail.com

Gauta 2018-10-01 